\title{
Tabularia
}

\section{Matilda, countess of the Perche (1171-1210): the expression of authority in name, style and seal}

Mathilde, comtesse du Perche (1171-1210) : expression de l'autorité par le nom, le style et le sceau

\section{Kathleen Thompson}

\section{OpenEdition}

\section{Journals}

Electronic version

URL: http://journals.openedition.org/tabularia/1546

DOI: 10.4000/tabularia.1546

ISSN: $1630-7364$

Publisher:

CRAHAM - Centre Michel de Boüard, Presses universitaires de Caen

Electronic reference

Kathleen Thompson, « Matilda, countess of the Perche (1171-1210): the expression of authority in name, style and seal », Tabularia [Online], Les femmes et les actes, Online since 18 July 2003,

connection on 02 May 2019. URL : http://journals.openedition.org/tabularia/1546 ; DOI : 10.4000/ tabularia. 1546 


\title{
Matilda, countess of the Perche (1171-1210): the expression of authority in name, style and seal
}

\author{
Mathilde, comtesse du Perche (1171-1210): \\ expression de l'autorité par le nom, le style et le sceau
}

\author{
Kathleen THOMPSON \\ Honorary Research Fellow \\ University of Sheffield \\ Kathleen.Thompson@shu.ac.uk
}

Abstract:

The career of Matilda of Saxony (1171-1210), wife of Count Geoffrey III of the Perche, illustrates the role of high born women in power politics in the twelfth/thirteenth centuries. After the exile of her father, Henry the Lion, duke of Bavaria and Saxony, she spent her life in western Europe, where she was known by the name of her maternal grandmother, the Empress Matilda. Her surviving acts suggest that her husband exploited her links with the Angevin dynasty, and her seal was used with her husband's to authenticate both his own and their joint acts, while its imagery may also have been intended to indicate her royal connections.

Keywords: Women, power, names, titles, Perche, acts, style, seals.

Résumé:

La carrière de Mathilde de Saxe (1171-1210), épouse du comte Geoffroy III du Perche illustre le rôle joué par des femmes de haute naissance en matière de pouvoir et de politique aux XII et XIII' siècles. Après l'exil de son père, Henri le Lion, duc de Bavière et de Saxe, elle passa sa vie en Europe de l'ouest où on la connaissait sous le nom de sa grand-mère maternelle, l'impératrice Mathilde. Les actes qui ont survécu suggèrent que Geoffroy III exploitait les liens que son épouse entretenait avec la dynastie angevine. Les sceaux de Mathilde et ceux de son mari étaient utilisés conjointement pour authentifier les actes qui les impliquaient tous les deux ou qui impliquaient uniquement le mari. Quant à la symbolique du sceau de Mathilde, elle a peut-être été conçue pour souligner les liens de la comtesse avec la royauté.

Mots-clés: Femmes, pouvoir, noms, titres, Perche, actes, dénomination, sceaux.

In July 1189 shortly after Richard the Lionheart's inauguration as duke of Normandy, Richard's niece, Matilda, was married to Geoffrey, eldest son of Rotrou, count of the Perche ${ }^{1}$. The daughter of Henry the Lion, duke of Saxony and Matilda, eldest daughter of King Henry II of England, Matilda shared a common ancestor with her new husband in that both were descended from William the Conqueror and it may be

1. The author is grateful for the comments of David Crouch and Susan Johns during the drafting of this paper. 
that a dispensation was required. If there were any difficulties of this kind they were overcome, for the marriage was part of Richard's strategy to ensure the security of his realm while he undertook his crusading obligations ${ }^{2}$. The study of Matilda's career therefore contributes to our understanding of political events of the late twelfth and early thirteenth century. The corpus of her surviving acts, both as wife of the count of the Perche and as mother of the next count, however, also provides an insight into women's access to power and the conventions that were adopted to express that access.

Matilda had been born in Germany in $1171^{3}$ and had come to the Anglo-Norman realm when her father had been exiled in 1180, but neither she, nor her younger brother Otto, accompanied their parents when they later returned to Germany ${ }^{4}$. On her marriage in 1189 she brought an extensive dowry to the Rotrou family, consisting of holdings in Suffolk, Essex and Kent, which had formerly been the property of Henry of Essex, an important English baron ${ }^{5}$. During the absence of her husband and fatherin-law on the Third Crusade, Matilda was active in the running of the Perche and it is likely that she had a son, Geoffrey ${ }^{6}$. Matilda's husband became count of the Perche after his father's death at Acre in July 1191, but did not return from the Holy Land until 1192.

Throughout the 1190s Count Geoffrey dealt with the political implications of the rivalry of his relatives, the French and English kings, for Geoffrey was himself the cousin of the French king, Philip Augustus, through their respective mothers, Matilda and Adela of Blois-Champagne, while his wife was the niece of the English kings, Richard and John. Geoffrey died in April 1202 as he prepared to embark on the Fourth Crusade and his brother, Stephen, assumed command of the Percheron forces. Matilda was left to control the Perche on behalf of her second son, Thomas, who had probably been born around $1193^{7}$. During the reign of her uncle John Matilda needed considerable political acumen to retain her son's English lands and her own dowry land. King Philip Augustus was able to exercise his rights as overlord of the counts of the Perche and arranged a second marriage for the widowed countess in 1204-1205, when she became the wife of Enguerrand de Coucy.

Matilda died in January 1210, when King John seized her dowry and all the other family lands in England. Her son, Thomas, was a promising young man, but he was killed at the Battle of Lincoln in 1217 and the independent line of the Rotrou counts

2. Roger of Howden, Chronica, ed. William StubBS, 4 vol. (Rolls Series, LI), 1868-1871, III, p. 3; THOMPSON, Kathleen, Power and border lordship in medieval France: the county of the Perche, 10001226, Woodbridge, The Boydell Press, 2002, p. 109.

3. ARNOLD OF LÜBECK, Chronicle of the Slavs, MGH SS, XXI, Hannover, 1869, p. 116.

4. Murray, Alan, "Richard the Lionheart, Otto of Brunswick and the earldom of York: Northern England and the Angevin succession, 1109-91", Medieval Yorkshire, 23, 1994, p. 5-12.

5. Gesta regis Henrici secundi, ed. William STUBBS, (Rolls Series, XLIX), 1867, II, p. 73; Curia regis rolls, London, 1923, XIII, n 684.

6. ThOMPSON, Power and border lordship..., p. 116.

7. Ibid, p. 145 
of the Perche became extinct with the death in 1226 of Matilda's brother-in-law, William, bishop of Châlons-en-Champagne and count of the Perche.

\section{Matilda's acts}

Matilda's acts were identified and collected in the course of preparing a study on the counts of the Perche, and a handlist forms appendix 1, containing references to twenty seven acts. Some documents survive in the form in which the countess herself could have seen them: there are nine of these originals ( $n^{\text {os }} 3,6,7,8,10,11,16,17,18$ ). Others are preserved in the record books or cartularies of religious houses to which the countess or the beneficiary of one of her acts gave property: there are six of these texts $\left(n^{\circ} 2,5,9,13,21,25\right)$. Some are preserved in the transcriptions of antiquarians, such as André Duchesne, who probably saw the documents that the countess would have seen $\left(n^{\text {os }} 1,4,12,15,26^{8}\right)$. Finally there is a group of acts, whose existence can be inferred from later references to them. Some, for example, are preserved in the body of others' confirmations ( $\left.\mathrm{n}^{\text {os }} 19,20\right)$. Rent rolls and necrologies can also contain references to property concessions without preserving the text of the act itself ( $n^{\text {os }} 14,22$, $23,24)$. One act is referred to in the records of the English crown $\left(n^{\circ} 27\right)$.

Of these acts:

- sixteen are documents which report a joint act by the countess and her first husband, Count Geoffrey;

- nine are documents in which the countess acted alone; and,

- two report an act apparently made jointly with her brother-in-law, Stephen of the Perche.

In addition, there are thirteen acts in which Count Geoffrey describes the participation of his wife, either conceding or approving his action ${ }^{9}$. It is rare for the documents to be dated or for their draftor to be identified within the text.

8. Arch. dép. Orne, IG 1071/3, p. 1, a catalogue of the acts of Toussaint (Mortagne), refers to the countess's act of foundation, but the text must be reconstructed from the information given by Léonard BART DES BOULAIS, Recueil des antiquitéz du Perche, comtes et seigneurs de la dicte province ensemble les fondations, bâtiments des monastères et choses notables du dict païs, ed. Henri ToURNOÜER, Mortagne (Notes et documents sur la province du Perche), 1890, p. 160-161, and Gallia Christiana, XI, col. 692.

9. Cartulaire de Marmoutier pour le Dunois, ed. Emile LECESNE, Châteaudun, Lecesne, 1874, $\mathrm{n}^{\circ}$ CCIII; Cartulaire de Notre-Dame de Chartres, ed. Eugène de BUCHÈRE de LÉPINOIS and Lucien MERLET, Chartres, Société archéologique d'Eure-et-Loir, 1865, n CXXXIV; Cartulaire de l'Abbaye de Notre-Dame de la Trappe, ed. Hyacinthe de CHARENCEY, Alençon, 1889, p. 16; Abbaye royale de Notre-Dame des Clairets: histoire et cartulaire 1202-1790, ed. Vt. Hector de SOUANCÉ, Nogent-le-Rotrou, 1894, n II; BL, ms Cotton Vitellius, A XI, fol. 105 published as The cartulary of Bradenstoke Priory, ed. V. C. M. LONDON, Devizes, Wiltshire Record Society, XXXV, 1979, n² 235; Cartulaire des abbayes de SaintPierre de la Couture et de Saint-Pierre de Solesmes, publ. par les bénédictins de Solesmes, Le Mans, 1881, $\mathrm{n}^{\circ} \mathrm{CLXV}$; Chartularium insignis ecclesiae Cenomannensis quod dicitur liber albus capituli, ed. A. Cauvin, Le Mans, 1869, no XXV; Cartulaire de l'abbaye de la Sainte-Trinité de Tiron, ed. Lucien MERLET, Chartres, Société archéologique d'Eure-et-Loir, 1883, n CCCLXXVII; Arch. dép. Orne, H 1846 (published as Cartulaire de l'Abbaye de Notre-Dame de la Trappe), p. 457-458; Obituaires de la province de Sens, 
Joint acts of the count and countess represent 17 per cent of the corpus of the count's acts, while joint acts of his father and mother represent $4 \%$ of Count Rotrou's corpus of surviving acta. Only two independent acts by Geoffrey's mother, Countess Matilda, are known, but no acts issued independently by his grandmother, Countess Hawise, have been traced. The surviving acts bear out existing perceptions about women's legal position in the eleventh and twelfth centuries ${ }^{10}$. While she was the wife of Count Geoffrey, Matilda did not issue acts alone, except for one singular document which is described below.

Five of the sixteen documents in which Matilda acts with her husband relate to her English dowry land ( $\left.n^{\text {os }} 1,7,10,11,20\right)$. Two further grants have been located that appear to relate to Matilda's dowry land in which the count acts without his wife. The first is a grant to Osbert fitz Hervey, the king's justice, of land at Leyland and Dagworth in Suffolk ${ }^{11}$ and the second grants Robert de Scales the advowson of Wetherden in Suffolk ${ }^{12}$. Neither act is dateable except within the limits of Geoffrey's rule as count of the Perche (1191 - 1202), but the presence of men with English toponymics in the first act suggests that it was given in England. Both acts refer to tenure from Geoffrey and his heirs, and Geoffrey warrants his grant to Osbert. His concession to Robert is not warranted and apparently follows a lawsuit (de qua contentio fuit inter me et dictum Robertum). It may be that these acts were given in England in the absence of the countess and in response to specific situations for which there was no opportunity to obtain her consent quickly.

Of the sixteen surviving joint acts of the count and countess, two involve property in England which was not part of the countess's dowry. First between 1192 and 1202 the count and countess gave the Augustinian priory of Southwick in Hampshire two virgates of land at Aldbourne in Wiltshire ( $\left.n^{\circ} 21\right)$. This manor had been held by Geoffrey's family intermittently since the beginning of the twelfth century and had no connection with the countess's dowry, but the countess's participation is particularly emphasised. Second, between 1194 and 1202 the count and countess endowed a small Augustinian priory at Sandleford (Berks.), just outside Newbury $\left(n^{\circ} 19\right)$. Again the countess had no connection with the area for Geoffrey's interests in Berkshire were derived from his grandmother, Hawise of Salisbury, the second wife of Count Rotrou II ${ }^{13}$.

II, ed. Auguste Molinier and Auguste Longnon, Paris, 1906, p. 389; BnF, Coll. Dupuy, vol. 222, p. 127; Alençon, Bibl. mun., ms 112, p. 13; BnF, ms fr. 24133, p. 303.

10. SHeridan WALKer, Sue, "Introduction", in Wife and Widow in medieval England, ed. Sue SHERIDAN WALKer, Ann Arbor, Mi., University of Michigan Press, 1993), p. 3. For a specific investigation to test the perception, JoHns, Susan, "The wives and widows of the earls of Chester, 1100-1252; the charter evidence”, Haskins Society Journal, 7, 1995, p. 117-132.

11. PRO E210/1532, discussed in Thompson, Power and border lordship..., p. 176: Tenendum de me et heredibus meis ille et heredes sui libere et quiete et honorifice et hereditarie per sevitium vicesim partis $i$. militis pro omni servitio et consuetudine et exactione.

12. B. L., ms Egerton 3137, fol. $101 \mathrm{v}^{\circ}$ : Tenenda de me et heredibus meis ei et heredibus suis inperpetuam haeditatem salvo servitio meo.

13. Dugdale, William, Monasticon Anglicanum, ed. J. STEVENS, London 1817 (repr. 1846), VI, p. 565. 
The countess may have acted jointly with her husband on some occasions because the property involved came from her dower. If that was the case then the countess's dower may have been located at Nogent-le-Rotrou. She was joint donor with her husband of the following sums to be paid from the the prepositura at Nogent: 60 s annually to the leperhouse of Grand-Beaulieu in Chartres; one penny a day to the Grandmontine house at Chêne Galon; $£ 20$ annually to the abbey of Fontevraud; $£ 10$ annually from the market to the abbey of Tiron; and three measures of wine annually to the Carthusian house at Val-Dieu ( $\left.{ }^{\text {os }} 2,4,6,22,26\right)$.

Eight of the nine acts in which Countess Matilda acted alone can be dated to her widowhood ( $\left.\mathrm{n}^{\text {os }} 3,5,9,13,14,15,17,27\right)$. Two have the purpose of furthering her husband's spiritual welfare, a traditional activity among noble widows $\left(n^{\text {os }} 3,13\right)^{14}$. She endowed additional anniversaria, this time in the cathedral of Chartres, and founded a collegiate church at Mortagne, where two chaplains were to pray for the soul of her husband. Two others have the stated purpose of carrying out activities that the count himself had intended to make, but was presumably prevented by the speedy onset of his final illness ( $\left.n^{\text {os }} 5,17\right)$. The grant of a burgher at Nogent-le-Rotrou to Perseigne mirrors other grants Geoffrey made to religious houses, but the foundation of the nunnery at Clairets was a significant departure from the earlier patronage of the Rotrou family. Geoffrey and his predecessors had seldom chosen to patronise female religious and it may have been Matilda's intention to retire to her new foundation ${ }^{15}$.

In addition to these benefactions the countess undertook a series of business transactions. She administered her husband's debts, incurred in the course of planning his departure for the new crusade. She undertook a debt of $\mathfrak{E} 300$ owed to William Marshal ( $\left.n^{\circ} 27\right)$ and she settled outstanding obligations to Lawrence Flaaut ( $\left.n^{\circ} 9\right)$. Two other acts suggest that she transacted routine business on behalf of her son, Count Thomas, in confirming donations made to the college of St. John at Nogentle-Rotrou and in notifying the purchase of land by her servant, Osanna ( $\left.n^{\text {os }} 14,15\right)$. In the early months of her widowhood, she appears to have acted with the advice of her brother-in-law, Stephen, whose specific approval is given to her grant to Chartres $\left(n^{\circ} 5\right)$ and her undertaking to Lawrence Flaaut $\left(n^{\circ} 9\right)$. In addition she may have acted jointly with Stephen in confirming grants to Tiron $\left(\mathrm{n}^{\text {os }} 23,24\right)$. It is possible that this joint administration dates from the very last days of Count Geoffrey's life (March 1202), when Geoffrey's grant to the servant, Osanna, was sealed by Matilda and Stephen: Quod ut ratum sibi perpetuo maneat et pacifice atque quiete deinceps

14. GEARY, Patrick J., Phantoms of remembrance: memory and oblivion at the end of the first millenium, Princeton, N. J., Princeton University Press, 1994, esp. chap. 2.

15. Geoffrey's grandfather, Count Rotrou II, had granted property to the Cluniac nunnery of Marcigny, where the Countess Adela of Blois had retired, Book of Fees, London, His Majesty s Stationery Office, 1921-1923, II, p. 738. His father had patronised the Fontevraudine convent at Belhomert on the borders of the Perche, BnF, ms fr. 24133, p. 310, a joint benefaction with his mother, Countess Hawise. Count Geoffrey himself had also patronised this house, possibly on his deathbed, on behalf of his sister, Oravia, BnF, ms fr. 24133, p. 303. 
possideat sigilli nostri et uxoris nostrae Matildis et fratris nostri Stephanis robur et munimen praesenti chartae apponi fecimus ${ }^{16}$.

The countess's last dateable act appears to have been that given at La Loupe in July 1204, when the foundation charter for the Cistercian nunnery of Clairets was enacted. If the countess had longer term intentions of entering her foundation, she was to be disappointed. Presumably at King Philip's behest she was married to to Enguerrand de Coucy and could no longer act independently ${ }^{17}$. No joint acts of the countess and her second husband have survived.

\section{Matilda's Name}

Matilda was the eldest child of the marriage between Henry the Lion, duke of Bavaria and Saxony and his second wife, Matilda, eldest daughter of King Henry II of England, duke of Normandy and count of Anjou. Like her mother, she might have been given her paternal grandmother's name, but Henry the Lion already had a daughter by his first marriage and his mother's name, Gertrude, was borne by the daughter of that marriage ${ }^{18}$. For his new daughter Duke Henry looked further back in his family tree, choosing Richenza, and she used this name until the family came in exile to the Anglo-Norman realm in the $1180 \mathrm{~s}^{19}$. From then on Duke Henry's daughter used her mother's name, Matilda, which was also that of her maternal great grandmother, the Empress Matilda.

The associations of the two names are interesting. The name Richenza had been borne by Henry the Lion's maternal grandmother, Richenza of Northeim, who had been crowned empress in Rome with her husband Lothar III in 1133. It was from Richenza's family that Henry the Lion had inherited Brunswick and Luneberg and the empress was a formidable personality. When her husband's designated successor, her son-in-law, Henry the Proud, was set aside in favour of Conrad III, Richenza had led the resistance to the new emperor, and after her son-in-law's death, she had promoted the claims of her grandson, Henry the Lion. The choice of her name was therefore a recognition by Henry the Lion that he owed much to his maternal grandmother ${ }^{20}$. An alternative name for the new daughter of Henry the Lion might, of course, have been Matilda. It too had been borne by a well-respected empress, the wife of Lothar III's predecessor, Henry V (1106-1125). Matilda was the daughter of the English king,

16. Abbaye royale de Notre-Dame des Clairets..., $\mathrm{n}^{\circ}$ II.

17. The marriage may have taken place, or at least been projected as early as 1203 , for Enguerrand refers to himself as Ingerrannus dominus Cociaci et comes Perticensis in that year, Cartulaire de l'abbaye de Notre-Dame de Ourscamp, ed. M. Peigné-Delacourt, Amiens, 1865, nº DCCXXXV.

18. Gertrude was recognised as her father's heir until sons were born from his second marriage to Matilda, daughter of King Henry II, Die Urkunden Heinrichs des Löwen, Herzogs von Sachsen und Bayern, ed. Karl JORDAN, MGH, Weimar,1941-1949), $\mathrm{n}^{\text {os }} 77,87$.

19. Jordan, K., Henry the Lion; a biography, trans. by Paul Stephen FalLA, Oxford University Press, 1986, p. 183.

20. Ibid., p. 23 
Henry I (1100-1135), and after the death of her first husband, she returned to her father's court to be his acknowledged heir and to marry Geoffrey, count of Anjou ${ }^{21}$. Her son, King Henry II of England, had chosen her name for his eldest daughter, who in 1168 had become the wife of Henry the Lion.

It is not known when the decision to use the name Matilda in preference to the name Richenza was taken, why it was taken nor who took it. It may simply reflect the fact that the name Richenza was unfamiliar in the Anglo-Norman realm. Alternatively, Duke Henry may have decided that it was wise to pay a compliment to the family of his father-in-law and host. He did not choose to change the names of his sons, however. The distinctly imperial name of Otto, never before used in his family, was retained by his son, who had been born in 1177, although the youngest son, born at Winchester in 1184, was given a name rich in Anglo-Norman association, William $^{22}$. There is a possibility, however, that the decision reflected a conscious decision on the part of the family or even the individual herself. It was not unusual for women to adopt a new name upon marriage. The Byzantine empress, Irene, had begun life as Bertha of Sulzbach and there was a precedent in the English royal house, when the Scottish princess, Edith, daughter of Malcolm Canmore and St. Margaret, had chosen to take the name of her mother-in-law, Matilda ${ }^{23}$. In a society where a woman's status and ultimately access to power depended upon the marital alliance she made, the opportunities available for Richenza-Matilda in her grandfather's realm were greater than those in the empire, where her father's power had been broken by the emperor Frederick Barbarossa. It may be, therefore, that her family and/or Matilda of Saxony chose to make her career in the Anglo-Norman realm and that the use of her mother and great-grandmother's name was an indication of this decision.

Certainly, when Henry the Lion returned to Germany in the mid 1180s, his daughter remained in England and as the decade passed she became the most eligible of King Henry II's female relations. His daughters were all married, while his five sons by Eleanor of Aquitaine produced only two surviving direct heirs: Eleanor and Arthur of Brittany (born respectively 1182-1184 and 1187) ${ }^{24}$. Matilda of Saxony was sought in marriage by two kings, Bela of Hungary and William the Lion of Scotland, but neither was rewarded with the royal granddaughter and found their queens respectively among the widowed royal daughters-in-law and the royal cousins. Matilda's marriage to Geoffrey was thus a sign of the greatest favour to the Rotrou family.

21. Chibnall, Marjorie, The Empress Matilda: Queen consort, Queen mother and Lady of the English, Oxford, Blackwell, 1991.

22. Roger of Howden, Chronica, IV, p. 116

23. The deeds of Frederick Barbarossa: Otto of Freising and his continuator, Rahewin, trans. Charles Christopher Mierow and Richard EMERY, New York, W.W. Norton, 1966, p. 178, note 22; Prof. Crouch has recently suggested that the Empress Matilda herself had an alternative English name, Aethelic, The Normans: the history of a dynasty, London \& Hambledon, 2002, p. 160.

24. GILlingHAM, John, Richard I, London, Yale University Press, 1999, p. 39, 69, 133; CraIG, Malcolm A. , "A second daughter of Geoffrey of Brittany", Bulletin of the Institute of Historical Research, 50 (1977), p. 112-115. 
Matilda refers to her ancestry only once in her acts. Between 1192 and 1202 the count and countess of the Perche gave the Augustinian priory of Southwick in Hampshire two virgates of land at Aldbourne in Wiltshire ( $\left.n^{\circ} 21\right)$. This manor had been held by Geoffrey's family intermittently since the beginning of the twelfth century and had no connection with the countess's dowry, but the countess's participation is particularly emphasised. Rather than being simply "the countess" or Geoffrey's "wife", she is described as the niece of the illustrious King Richard and the daughter of Henry duke of the Bavarians and Saxons. This is the only reference to King Richard in the countess's surviving acta, as well as her only reference by name to her father, Duke Henry. It is tempting to date this act to the second half of 1195. After King Richard's return from his captivity in the empire, Count Geoffrey had been deprived of his English lands, including Aldbourne, probably as punishment for supporting the rebellion of Richard's younger brother, John ${ }^{25}$. This land was restored in 1195 and in August of that year the countess's father, Duke Henry the Lion, died. A judicious benefaction to an English house, favoured by the king, made jointly with his well-connected wife, would acknowledge a new rapprochement between Geoffrey and King Richard.

\section{Matilda's style}

When Matilda acts jointly with her husband, Count Geoffrey, she is usually described as the countess. On only three occasions is her title not used and she is described simply as Geoffrey's wife ( $\left.\mathrm{n}^{\mathrm{os}} 16,18,25\right)$; in each case a benefaction is made to a French house from Rotrou family resources. It may be that the intention was to stress Matilda's role in the family as wife because she was influential in persuading her husband to make the benefaction. A joint act granting $100 \mathrm{~s}$. annually from the prepositura at La Perrière to the Cistercian house at Perseigne, might well be the result of the pastoral relationship between the influential abbot, Adam of Perseigne, and the countess, to whom he addressed a letter of spiritual advice $\left(n^{\circ} 16\right)^{26}$. In other acts to French houses, Geoffrey acted alone, implying the decision and the resources were his alone, and in those acts he used other methods to associate his wife, who is described simply as his wife and not as countess. When Geoffrey resigned a right to hospitality (procurationem) at the priory of Chuisnes, for example, in return for an annual payment of 100 s., he did so at the wish and with the approval (volentibus et concordentibus) of Matilda, his wife, Geoffrey, his son, and Stephen his brother ${ }^{27}$. A second act resigns another right to hospitality, this time called a gistum, at Grandhoux to the cathedral chapter of Chartres ${ }^{28}$. Again his wife, Matilda, is associated with the act, together with Geoffrey's brothers: concedente uxore mea Mathilde, et filio meo Gaufrido et fratribus meis Stephano, Rotrodo, Theobaldo, Wuillelmo.

25. THOMPSON, Power and border lordship..., p. 118-119.

26. AdAm of Perseigne, Lettres, ed. Jean Bouvet, Paris, Editions du Cerf, 1960, p. 236-249.

27. Cartulaire de Marmoutier pour le Dunois, ed. Emile MABILLE, Châteaudun, $1874, \mathrm{n}^{\circ} \mathrm{CCIII}$.

28. Cartulaire de Notre-Dame de Chartres, ed. Eugène de BUCHÈRE DE LÉPINOIS et Lucien MERLET, Chartres, 1865, $\mathrm{n}^{\circ}$ CXXXIV. 
It would be unwise to overstate this principle, however, for in an act of confirmation to the abbey of La Couture in le Mans, covering English property given by Geoffrey's ancestors Matilda appears as both countess and wife: cum assensu et voluntate Matildis comitisse uxoris nostre et Gaufridi filii nostri and on this occasion he also chose to append her seal: Quod ut firmum et inconcussum habeatur sigilli nostri et sigilli Matildis comitisse uxoris nostre auctoritate et testimonio confirmavymus ${ }^{29}$. Similarly in a confirmation to the Salisbury family foundation of Bradenstoke priory, where his great grandparents, Walter and Sibyl of Salisbury, were buried, Geoffrey associates his countess and wife by linking her salvation with his own: pro salute anime mee et Matildis comitisse uxoris mee et omnium antecessorum meorum et amicorum ${ }^{30}$.

In the acts which she gave individually Matilda always styles herself Matilda, Countess of the Perche. Usually she uses the adjectival form favoured by her husband's family since the early twelfth century: Comitissa Perticensis - the Percheron countess. On three occasions the form Comitissa Pertici - countess of the Perche is used. The proportion of usage reflects that of her husband's acts. On one occasion $\left(n^{\circ} 8\right)$, however, the fomula dei gratia - by grace of God is added, and there are hints of Matilda's particular status in this act and her husband's act that parallels it.

\section{Matilda's seal}

No impressions of the countess's seal have yet been traced, although there are references to the seal in eighteen acts. A seventeenth-century abstract of a joint act by Count Geoffrey and the countess in favour of Fontevraud depicts the seal however. It shows a standing lady, full face, whose head is bound with a fillet. She holds a bird in her left hand and what appears to be a rod in her right hand, although it is possible that the draughtsman has depicted as a rod the branch that many noblewomen are portrayed holding on their seals ${ }^{31}$. The counterseal is described as three bends. The impression was made on green wax, mounted on white silk cords ${ }^{32}$. A briefer reference to the countess's seal in the seventeenth-century catalogue of the records belonging to the Carthusian house at Val-Dieu also describes the impression of countess's seal on green wax ${ }^{33}$.

Matilda mentions her seal in six of her personal acts and eight of her joint acts. In addition, her seal is mentioned on four of her husband's acts, given with her ap-

29. Cartulaire des abbayes de Saint-Pierre de la Couture et de Saint-Pierre de Solesmes, Le Mans, E. Monnoyer, $1881, \mathrm{n}^{\circ}$ CLXV.

30. B. L., Cotton ms Vitellius A XI, fol. 105.

31. Cf. The early thirteenth-century seal of Basilia de Glisolles, Sceaux de chartes de l'abbaye de la Noë conservées à la Bibliothèque nationale XII ${ }^{e}$-XIII ${ }^{e}$ siècles: inventaire, ed. Martine DALAS, Paris, Archives nationales, 1993, $\mathrm{n}^{\circ} 15$.

32. BnF, ms lat. 5480, p. 352.

33. Alençon, Bibl. mun., ms 112, fol. $13 \mathrm{v}^{\circ}$ : scellé de deux sceaux de cire verte aux double queue en l'un desquels est imprime l'image d'un homme a cheval tenant une espee en sa main \& en l'autre l'image d'une femme. 
proval or consent. While the standard study suggests that women's seals in twelfth and thirteenth century France were "confined to a strictly personal usage and not to have possessed the public dimension of the male's" ${ }^{34}$, Matilda makes it quite clear that her seal has authority. In conceding her husband's grant of a burgher at Nogentle-Rotrou to the abbey of Perseigne, she uses her seal to confirm her action: ego que huic eleemosine et donationi presens interfui et eam pro parte mea concessi, in testimonio ueritatis quod uidi et audiui sigilli mei caractere confirmaui ( $\left.\mathrm{n}^{\circ} 17\right)$. Her seal was also used in her husband's lifetime to corroborate her husband's action and in an act in favour of the cathedral at Le Mans, Count Geoffrey explicitly states this fact: Mathildis etiam comitissa, uxor mea, sigilli sui testimonio hoc idem corroboravit ${ }^{35}$.

This act was probably made at Le Mans in the difficult days after the death of King Richard, when it was unclear whether Arthur of Brittany or John of Mortain would secure the Angevin and Manceau inheritance. Count Geoffrey gave an undertaking to the canons of Le Mans and promised to obtain confirmatory letters from the king of France. It comes as no surprise therefore that the countess's participation was explicitly mentioned, since it would be wise to invoke the authority of both the Capetian and the Angevin families. However it is not the only act where the countess's authority is invoked through the physical presence of her seal. Count Geoffrey's act in favour of the abbey of La Couture also mentions her seal, as does the act in favour of the Charterhouse at Val-Dieu ${ }^{36}$. Finally as the count lay on his deathbed at Le Theil in the spring of 1202 he again used his wife's seal, this time with that of his brother, to give authority to an act ${ }^{37}$.

Matilda's marriage into the Rotrou family was clearly a sign of great favour by her uncle and the Countess's connections would be of enormous value. In the 1180s she spent time with her royal grandmother, Eleanor of Aquitaine, and she seems to have maintained close links with her kin $^{38}$. In 1188 she had visited her aunt, Queen Eleanor of Castile, and in 1199 she was with Eleanor of Aquitaine at Fontevraud during the period of mourning for King Richard ${ }^{39}$. Both these women had their own seals, as did the Empress Matilda, the countess's great-grandmother and it may be that their

34. BEDOS REZAK, Brigitte, "Women's seals, and power in medieval France 1150-1350", Women and power in the middle ages, ed. Mary ERLER and Maryanne KOWALESKI, Athens, Ga., University of Georgia Press, 1988), p. 61-82 at page 66.

35. Chartularuim insignis ecclesiae Cenomannensis quod dicitur liber albus capituli, ed. A. CAUVIN, Le Mans, 1869, nºXV (1191-1202, probably 1200).

36. Cartulaire des abbayes de Saint-Pierre de la Couture..., $\mathrm{n}^{\circ}$ CLXV: Quod ut firmum et inconcussum habeatur, sigilli nostri et sigilli Matildis comitisse uxoris nostre auctoritate et testimonio confirmavymus; Alençon, Bibl. mun., ms 112, fol. $13 \mathrm{v}^{\circ}$ : Ut autem haec donation firmius et fidelius permaneat venerabilis comes Gaufridus confirmavit eam et suo sigillo munivit \& sigillo uxoris suae.

37. Abbaye royale de Notre-Dame des Clairets..., $\mathrm{n}^{\circ}$ II: Quod ut ratum sibi perpetuo maneat et pacifice atque quiete deinceps possideat sigilli nostri et uxoris nostrae Matildis et fratris nostri Stephani robus et munimen praesenti chartae apponi fecimus.

38. Pipe Roll 33 Henry II (1186/7), London, Pipe Roll Society, 1915, p. 40.

39. Pipe Roll 34 Henry II (1187/8), London, Pipe Roll Society, 1925, p. 18; Calendar of documents preserved in France, ed. John Horace Round, London, 1899, $\mathrm{n}^{\circ} 1301$. 
practice influenced the countess ${ }^{40}$. The empress is shown seated and holding and orb and sceptre. While the countess's seal image shows her standing, the depiction of what may be a rod could derive from a sceptre ${ }^{41}$. There is some evidence that the rod had been used as a symbol of princely authority by Henry the Wrangler, a predecessor of Matilda's father as duke of Bavaria and it is interesting that the earliest written description this use of a rod in the Anglo-Norman world that Professor Crouch has been able to find is that of another woman, Sibyl of Tarragona, given by Orderic Vitalis $^{42}$. The rod and the fillet around the countess's head may hint at an authority beyond that of the wife of a count. It is possible that this perception was consciously fostered by the count and his wife ${ }^{43}$. There is just a hint of the evolution of their ideas in the documentation surrounding the gift of Gerard of Apres $\left(n^{\circ} 8\right)$.

The countess's act describes events at Mortagne in 1191 in her husband's absence with the Christian armies of the East, notifying the gift made by Gerard to the abbey of La Trappe, which he placed in the countess's hand: Girardus hanc elemosinam posuit in manu mea et ego suscepi illam abbatie conseruandam... No witnesses are mentioned and at the end of the act she uses the words teste me ipsa, a formula which was just beginning to prevail in her uncle, Richard's acts. It is not, however, the only record of events. Within the La Trappe's archive a smaller document is preserved, similarly prepared for sealing with one fold, but containing only a single slit for a tag and lacking the parchment tag which still survives on the countess's act. This document records the witnesses: Testes de dono Girardi de Aspris de terra de Barris quam dedit per manum $M$ comitisse Pertic' apud Mauritaniam... The terminology employed in the act is slightly different, too. The countess's first act indicates that she conveyed the land to the vicecomes: et manu tenendam uicecomitis qua fungebatur et in omnibus et per omnia defensandam liberam et quietam sicut meam, but this second document describes the act being made in the hearing of the seneschal and viarius in whose jurisdiction it lay: audiente Matheo tunc senescallo. et Hugone uiario. ad quem dominium illius terre pertinebat qui promisit comitisse super eadem elemosina se bonam pacem seruaturum monachis.

40. BnF, ms lat. 5480, p. 352. For Eleanor of Aquitaine's seal, Gordon, Donna Mildred, A translation of the letters and charters of Eleanor of Aquitaine, unpublished MA thesis, University of Alberta, 1970, XXI. A drawing of a lozenge-shaped seal was published by Charles MÉTAIS, Cartulaire saintongeais de la Trinité de Vendôme, Paris/Saintes (Archives historiques de la Saintonge et de l'Aunis, XXII), 1893, p. 103-104. It shows a woman standing, full face, and holding a bird in her left hand. She holds nothing in her right hand. A fragment of another seal is preserved in the Archives nationales, in which standing woman, full face, holds an orb in her left hand, photo, PERNOUD, Régine, Eleanor of Aquitaine, trans. P. WILES, London, Collins, 1967, opposite p. 32. Queen Eleanor of Castile's seal was apparently oval and the queen is depicted standing with a bird in her left hand, J. Gonzalez, El reino de Castilla en la epoca de Alfonso VIII, Madrid, Consejo Superior de Investigationes Cientificas Escuela de Estudios Medievales, 1960, I, p. 186.

41. Chibnall, The Empress..., plate 5. I am indebted to Dr Susan Johns for drawing this parallel to my attention.

42. Crouch, David, The image of aristocracy in Britain, 1000-1300, London, Routledge, 1992, p. 213, 211.

43. For a more detailed study of self perception and seal images, JoHns, Susan, Aristocracy and power in the twelfth-century Anglo-Norman realm (Manchester, 2003, forthcoming). 
One interpretation of these documents might suggest that the countess, newly arrived in the Perche and conscious of the active role in government played by her grandmother, Queen Eleanor and great-grandmother, the Empress Matilda, had taken it upon herself to act on her husband's behalf. She might have instructed a clerk in her household, trained in the practices of the English court, to draft the act for her, which might explain the use of the word vicecomes, hitherto not used of the Percheron counts' officials, together with the teste me ipsa conclusions, a formula which was becoming increasingly common in her uncle's acts. Alternatively she might have been empowered by her husband to act on his behalf, though this suggestion appears to be contradicted by acts where count Geoffrey's brother Stephen and seneschal, Warin of Lonray, issue acts jointly with the count ${ }^{44}$.

A contrary and perhaps more plausible interpretation is that the countess's act is in fact a post factum draft. It mirrors almost exactly her husband's act confirming Gerard of Apres' grant with only minor variations in personal and place name spellings and the substitution of the information that Matilda had placed the gift in the vicecomes' hands in place of Geoffrey's formulation that the gift had been placed in Matilda's hands, while the count was in peregrinatione iherolsolimat'. Perhaps the original record of the gift at Mortagne is the much smaller document that simply lists the witnesses: Testes de dono Girardi de Aspris de terra de Barris quam dedit per manum M comittisse Pertic' apud Mauritan'45. When the count returned, he issued his own notification of Gerard's gift, sealing it on the green wax, whose traces can still be found on the parchment tag. At much the same time a more formal record of the countess's role was drafted, which the countess then sealed. The language chosen for both the count's act and the account of the countess's action is very grand; there is a religious preamble and the use of the dei gratia formula. Both the count and the countess use the teste me ipso/a attestation and the countess refers to a vicecomes. All these factors hint at the countess's royal connections, although her father also favoured the dei gratia usage ${ }^{46}$.

It might be possible therefore to see the La Trappe acts as the first in a sequence by which attention was drawn to the countess's royal connections. The countess was the joint donor in an act restoring the Maison Dieu at Mortagne, which signalled the end of fighting across the Norman border ( $\left.n^{\circ} 12\right)$. In the period of reconciliation after King Richard's return her royal connections are specifically mentioned in the benefaction to Southwick Priory ( $\left.n^{\circ} 21\right)$ and she acted with her husband in the foundation of Sandleford Priory (n॰ 19). Geoffrey's claims to the English property that was given to Sandleford, together with that confirmed to Bradenstoke and La Couture, were all derived from his English grandmother, Hawise of Salisbury, and

44. For joint acts, BnF, Collection Duchesne, vol. LIV, p. 454 (Geoffrey and Stephen 1192); Alençon, Arch. dép. Orne H 5441 (Geoffrey and Warin).

45. The list is $121 \times 50+12 \mathrm{~mm}$., while the Countess's act is $190 \times 154+26 \mathrm{~mm}$.

46. Urkunden Heinrichs des Löwen..., XLVI ff. Die Urkunden Heinrichs, Herzogs von Sachsen und Bayern, ed. Karl JORDAN, MGH, Weimar, 1941-1949), $\mathrm{n}^{\text {os }} 77,87$. 
it is perhaps no surprise therefore that he should associate his wife, the king of England's niece, in its disposition. By the late 1190s when the confrontation between the French and English kings reached its height, the use of both the count and the countess's seals was an overt and powerful demonstration that the counts of the Perche had links with both sides.

\section{Handlist}

1 Bradsole

Geoffrey [count of the Perche] and his wife Matilda's confirmation of benefactions made by Walter Haket and his wife Emma, with the consent of William of Poltone and his heir Stephen, to the Premonstratensian abbey of St. Radegund at Bradsole (Kent) is recorded in the confirmation of their son, Count Thomas, 1189-1202.

$\mathrm{B}=$ Oxford, Bodleian Library, ms Rawlinson B461, fol. 20.

Pd. Dugdale, William, Monasticon Anglicanum, ed. J. STEVens, London, 1817 repr. 1846, VI, p. 941.

\section{Chartres. Grand Beaulieu}

Count G[eoffrey] and the Percheron countess M[atilda] grant for their anniversaria to the leperhouse of Grand-Beaulieu at Chartres an annuity of $60 \mathrm{~s}$. from the prepositura of Nogent and if the prepositus fails to pay at the appointed time he shall be liable to a weekly penalty of 10 s., 1192-1202.

Pd. Cartulaire de la léproserie du Grand-Beaulieu et du prieuré de Notre-Dame de la Bourdinière, ed. René MERLET and Maurice Jusselin, Chartres, Archives d'Eure-et-Loir (Collection des cartulaires chartrains), 1909, nº 153.

\section{Chartres. Cathedral}

Matilda, the Percheron countess, grants to the cathedral of Chartres $60 \mathrm{~s}$. angevin to endow her own anniversarium and $60 \mathrm{~s}$. to endow that of her late husband, Geoffrey the Percheron count. These sums are to be taken annually on the feast of the Purification of the Virgin from the revenues of Marchainville, which she and Geoffrey acquired together, Chartres, June 1202.

A = Chartres, Arch. dép. Eure-et-Loir, G 1459. Parchment 213mm x 96 mm + $19 \mathrm{~mm}$. Endorsed, s. XIII De anniuersariis Gaufridi comitis Perticensis et Matildis uxoris eius. Two central slits for sealing in a single queue, substantial amounts of green and cream silk?/linen? remain, no trace of seal. Joined to an act of Stephen of Sancere, assigning the annual $60 \mathrm{~s}$. and dated 1236.

$\mathrm{B}=$ Chartres, Arch. dép. Eure-et-Loir, G 134, caisse LXVII B16 (indexed). Pd. Cartulaire de Notre-Dame de Chartres, ed. Eugène de BUCHÈRE de Lépinois and Lucien Merlet, Chartres, 1865, $\mathrm{n}^{\circ}$ CLIX. 


\section{Chêne Galon}

Geoffrey the Percheron count and the countess M[atilda] grant the priory of Chêne Galon a penny a day from the revenues of the castles at Mortagne, Longpont, Mauves, Maisonmaugis, Bellême, Le Theil, La Perrière, Montisambert, Nogent, Rivray, Montlandon, La Ferrière, Nonvilliers and Montigny. They add the sum of 4 s. to be paid every Saturday from the prepositura at Mortagne and a payment at Easter of 60s. to fund their anniversaria to be paid from the prepositura of La Perrière by the serving praepositus without delays, 1192-1202 probably March 1202.

$\mathrm{B}=$ Paris, BnF, coll. Duchesne 54, p. 460.

Pd. a). Bry de la Clergerie Gilles, Histoire des pays et comté du Perche et duché d'Alençon, Paris, 1620, rev. Philippe SiguRET, Paris, 1970, p. 206 (in part). b). CEILLET DES Murs, Marc Anasthase Parfait, Histoire des Comtes du Perche de la famille des Rotrou, 943 à 1231, Nogent le Rotrou, 1856, p. 500-501 (French translation). c). COURTIN, René, Histoire du Perche, publiée d'après le manuscrit original et annoté par O. de Romanet et H. Le Tournoüer, Mortagne, 1893, p. 218-219 (French translation).

\section{Clairets}

Matilda, the Percheron countess, notifies the wish of her late husband, Geoffrey the Percheron count, to found an abbey at Boveria (? Bouvereau, Eureet-Loir, cant. Thiron, comm. Marolles-les-Buis) and her promise to him as he lay on his deathbed that she would carry out his intention. After consultation with both ecclesiastical and lay advisers the countess decided to build the abbey in the woods at Les Clairets and chose to grant it to nuns of the Cistercian order, who were established in the religious life by Reginald bishop of Chartres. The countess then granted the nuns Boveria with all its appurtenances and added an annual sum of ten marks payable on the feast of St. Rémy from her manor of Haughley in England, half the mill of Saint-Victor [? deRéno], the medietaria of Ponte and two arpents of meadow at Le Theil, a burgher at Nogent free from all dues, and the rents from two properties held by Robert Aie and William which lie inside the nuns boundaries. The countess also granted rights to timber, firewood, pasture and pannage for the nuns' pigs in all woodlands except those of Perchet, La Loupe, July 1204.

Pd. Abbaye royale de Notre-Dame des Clairets: histoire et cartulaire 1202-1790, ed. Vte Hector de SouANCÉ, Nogent-le-Rotrou, 1894, nº IV.

\section{Fontevraud}

Count Geoffrey and his wife the Percheron countess Matilda give to the abbey of Fontevraud to fund their anniversaria $£ 20$ from the prepositura of Nogentle-Rotrou to be paid twice yearly and if the prepositus fails to pay at the appointed times he shall be subject to a weekly penalty of 20 s., 1192-1202. 


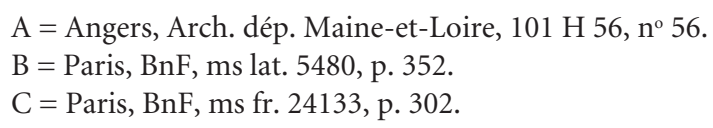

\section{Geoffrey fitz Perdriz}

Geoffrey count of the Perche and Matilda his wife grant to Geoffrey Perdris property at Eastwood, (Essex): two acres formerly held by Solomon, four acres formerly held by Sych' and five acres formerly held by Robert for $14 \mathrm{s.} 4 \mathrm{~d}$. and the marsh formerly held by Alurichus Havoc for $60 \mathrm{~s}$. and $6 \mathrm{~s}$. for tithes, due at Easter and the feast of St. Michael. Geoffrey received nine marks of silver de gersum for his confirmation and Matilda one mark of silver, 1192-1202.

A = B. L., ms Harley charter 54. g.26.

\section{La Trappe}

Matilda, by the grace of God, countess of Perche notifies the gift to the abbey of La Trappe made by Gerald of Les Apres of his property and rights in the land called Barres (Orne, cant. Moulins-la-Marche, comm. Les Genettes) which lies between Fretay (Orne, cant. Tourouvre, comm. Bresolettes) and Heris'uneaiam. For this concession Gerald received $£ 20$ angevin, his eldest son Arnold a chicken, his sons Warin 6 s. dunois, Hugh 5 s. and Waleran 5 s., while his wife Mary received two sextaria of grain and his daughter in law, Agnes, the wife of Arnold, a cow. Gerald placed this gift in the countess's hand and she handed it over to the vicecomes, giving the monks $100 \mathrm{~s}$. in alms herself, Mortagne 1191.

A = Alençon, Arch. dép. Orne, H 1846. Endorsed, XII s ? de bosco de barris. Parchment 190 x $154+26 \mathrm{~mm}$. One set of double slits for tag, tag intact, no seal. $\mathrm{B}=$ Paris, BnF, ms lat. 11060. Cartulaire de la Trappe, foliation unknown. Pd. Cartulaire de l'Abbaye de Notre-Dame de la Trappe, ed. Hyacinthe de CHARENCEY, Alençon, 1889, p. 458.

Second act

A = Alençon, Arch. dép. Orne, H 1846. Endorsed, twice Testes de dono Girardi de Aspris. Parchment 121 x 50+12 mm. One single slit for tag, tag and seal missing.

\section{Lawrence Flaaut}

Matilda countess of the Perche settles with Lawrence Flaaut the outstanding

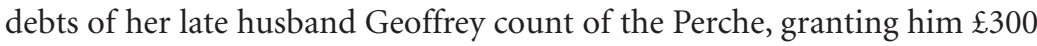
angevin in the forest of Bellême. She releases him from the obligation he incurred at the count's instruction to the Maison-Dieu at Mortagne, unless she herself is pressed for the same amount which she owes to the abbot and monks of Saint-Benoit-sur-Loire. If she is not released from her debt then she and Stephen of the Perche will transfer Lawrence's obligation to the house at La Chaise [a priory of Saint-Benoît], 1202.

B = Orléans, Arch. dép. Loiret, H 22, p. 185-186, nº 290. 


\section{Lawrence fitz Jordan}

Geoffrey count of the Perche and his wife, the countess Matilda, give and concede to Lawrence fitz Jordan of Paglesham the whole hundred of Rochford (Essex) to be held for an annual rent of $\mathfrak{E} 8$ due on the octave of Easter and the octave of St. Michael. The count and the countess will warrant the hundred to Lawrence and his heirs against all people (gentes), 1192-1202.

A = Canterbury Dean \& Chapter archives, carta antiqua R. 62.

\section{Lawrence fitz Jordan}

Geoffrey count of the Perche and the countess Matilda, his wife, give and concede to Lawrence fitz Jordan of Paglesham the land known as Turkelland, with all its appurtenances including the marsh, and the great marsh called Alfladenas to be held for an annual rent of $\mathfrak{E} 6$ payable in two instalments at the octaves of Easter and Saint Michael. The count and countess will warrant the property to Lawrence and his heirs against all men and all women, 1192-1202.

$\mathrm{A}=$ Canterbury Dean \& Chapter archives, Carta antiqua T. 27.

\section{Mortagne. Maison-Dieu}

Geoffrey count of the Perche and Matilda his wife grant to the Maison Dieu at Mortagne $\mathfrak{E} 32$ of revenue from their demesne in Mortagne to rebuild the house after the recent warfare and another $25 \mathrm{~s}$. from the same source for lighting to celebrate divine service in the hospital chapel of St. Nicholas, to be paid in the following way: $\mathfrak{E} 10$ on the Saturday after the Purification of the Virgin, $\mathfrak{E} 10$ on the Saturday after Ascension and $\mathfrak{E} 10$ on the Saturday after St. John the Baptist's day with the rest payable on St. Nicholas' day. If these sums are not paid on these days the prepositus or the receiver shall pay the Maison Dieu 10s. tournois for each week during which he defaults. The count establishes a prior, two priests and four nuns of the order of St. Elizabeth to care for the poor of the hospital and builds a lodging close to it. He grants rights of inspection of all leather and shoes sold in Mortagne and possession of all confiscations of unsatisfactory work. He establishes the confraternity of Mortagne shoemakers in the chapel of Maison-Dieu and they are to feed the poor people resident in the hospital on St. Nicholas' day. He also grants calfagium to the poor of the hospital in his forest of Bellême. Several other lords make benefactions by the same charter, Mortagne, 1195.

Pd. Bart des Boulais, Recueil des antiquitéz..., p. 156-159.

\section{Mortagne. Toussaints}

Notice of the lost foundation charter of the college of Toussaints, Mortagne, given by Countess Matilda, is preserved in an inventory of the college's 
charters. The countess gave a site at Mortagne for the construction of a collegiate church and established there two chaplains to pray for the soul of her husband, Geoffrey. She endowed it with $£ 12$ from each of the prepositure at Moulins-la-Marche and Mortagne and the profits of the fair on St. Andrew's day at Mortagne.

A witness list is provided by reference to the act in Gallia Christiana, Longpont, March 1203.

C = Alençon, Arch. dép., Orne IG1071/3, p. 1.

Pd. (in part) a). BART des BOULAIS, Léonard, Recueil des antiquitéz du Perche, comtes et seigneurs de la dicte province ensemble les fondations, bâtiments des monastères et choses notables du dict païs, ed. Henri TOURNOÜER, Mortagne (Notes et documents sur la province du Perche), 1890, p. 160-161. b). Gallia Christiana, XI, col. 692.

\section{Nogent-le-Rotrou. Collège de Saint-Jean}

Matilda ${ }^{47}$, countess of the Perche's confirmation of the donations made to the collège de Saint-Jean by the clerk, Warin, is recorded in the college's obituary, ?1202-1210.

C = Chartres, Arch. dép. Eure-et-Loir, G 3485.

Pd. Obituaires de la province de Sens, II, ed. Auguste Molinier and Auguste LONGNON, Paris (Recueil des historiens de la France. Obituaires), 1906, p. 389.

\section{Osanna}

Matilda countess of Perche notifies that her domicilla Osanna has bought the land of Meslair from Gervase of Mauchenai and William Flauut and has been granted seisin of it by Thomas of Fai. She and her son, Thomas, bear witness to it. Mauves, July 1203.

$$
\text { C }=\text { Paris, BnF, coll. Duchesne 54, p. } 454 .
$$

\section{Perseigne}

Geoffrey the Percheron count and his wife Matilda give to the abbey of Perseigne $100 \mathrm{~s}$. percheron from the revenues of their prepositura of La Perrière which is to be paid annually on the first Sunday after St. Rémy's day. The sum of 10s. is payable by the count and his heirs if these payments are not made by his prepositus, 1192-1202.

A = Le Mans, Arch. dép. Sarthe, H 930.

Pd. Cartulaire de l'abbaye Cistercienne de Perseigne, ed. Gabriel Fleury, Mamers, $1880, n^{\circ}$ LXVII (in part).

47. Matilda is mistakenly described in the obituary as the mother of Geoffrey and Stephen. Since Warin was given the property by Count Geoffrey and his brother, Stephen, and the act was later confirmed by the Countess Matilda, she must be Geoffrey's wife, not his mother, who was dead by 1184 . 


\section{Perseigne}

Matilda countess of the Perche notifies that her husband Count Geoffrey of the Perche granted to the abbey of Perseigne a burgher, Baldwin Bovet of Nogentle-Rotrou, who was exempt from all comital exactions, but the count had failed to confirm this gift because of an oversight of the monks [propter negligentiam eorum]. The countess, who had been present when the gift was made and consented to it, confirms it, 1202-1210.

A = Le Mans, Arch. dép. Sarthe, H 930. Parchment 130 x $74+18$ mm. Endorsed sXIII ? carta Matildis comitissa Pertici de eo quod dedit burgensem unum apud Nogentem ecclesie Persenie. Double set of slits for tag, tag remains, approx. $20 \mathrm{~mm}$ of queue has been cut away. Pd. Cartulaire de l'abbaye Cistercienne de Perseigne..., $\mathrm{n}^{\circ}$ CCCLXV.

\section{Saint-Évroult}

Geoffrey count of the Perche and Matilda his wife notify their grant to the abbey of Saint-Évroult of the church of Saint-Nicholas of Moulins-la-Marche (Orne, chef-lieu de cant.) and two thirds of all tithes and offerings, while the other third is to go to the priest who ministers there. Geoffrey adds the chapel of Saint-Pierre within the castle of Moulins, the upkeep of which is to be paid for from his woods of Moulins. Two monks are to be sent from Saint-Evroult to staff the chapel of Saint-Pierre, together with a priest, and they are to receive the revenues of Saint-Nicholas on the advice of the prior of Saint-Laurent. Geoffrey also concedes his land of Putrel, estimated at about twenty acres, and a fair in the town of Moulins on the feast of St Nicholas according to the customs of the fair of St. Lawrence whereby the monks receive the profits of justice and all tolls in the town of Moulins for the nine days preceding the feast, 1195-1202.

$$
\begin{aligned}
& \mathrm{A}=\text { Alençon, Arch. dép. Orne, H } 721 . \\
& \mathrm{B}=\text { Paris, BnF, ms lat. 11055, fol. } 36 .
\end{aligned}
$$

\section{Sandleford}

Geoffrey count of the Perche and Countess Matilda endow the Augustinian priory of Sandleford (Berks.) with the church and all the land at Sandleford, together with the wood known as Brademore and with all the land on both sides of that wood that is, bounded by the watercourse known as Aleburn from the bridge at Sandleford to the Alburnegate, then by the road which runs from Alburnegate towards Newbury up to the croft of William the huntsman and on the third side from there along the road to the croft of Robert fitz Rembald and on the fourth side up to the bridge at Sandleford. The right to build a mill is granted together with an annual sum of thirteen marks of sterling to be taken from the mills of Newbury every four weeks. When the prior dies one of the remaining canons is to be chosen in his place, 1194-1202. 
Pd. a) Monasticon, VI, 565 from an inspeximus by Stephen Langton of Hubert Walter's charter of confirmation. b) Acta Stephani Langton Cantuariensis archiepiscopi AD 1207-1228, ed. Kathleen MAJOR, Oxford, Canterbury and York Society, 50 (1950), $\mathrm{n}^{\circ} 34$.

\section{Simon son of Odin}

The grant made by Geoffrey of the Perche and his wife Matilda to Simon son of Odin of an island called La Ruwesand in Suffolk and rights in the wardenship of park of Haughley is recorded in a grant by Simon's descendant, Roger of Astwyk, 1189-1202.

$\mathrm{B}=\mathrm{PRO} \mathrm{E} 40 / 3873$

Pd. Descriptive catalogue of ancient deeds, 6 vol., London, 1890-1915, III, A 3873, p. 5.

\section{Southwick}

Geoffrey count of the Perche and his wife Countess Matilda, niece of King Richard and daughter of Henry duke of Bavaria and Saxony, grant the Augustinian priory of Southwick (Hants.) two virgates of land at Aldbourne (Wilts.), formerly held by Richard Anglicus and Robert Heiward, together with their associated property including the holdings (mansuagiis) in Weststret, to pay for the mass wine. The donors are accepted into confraternity by the priory and their anniversaries are to be celebrated at the house, 1192-1199.

$\mathrm{B}=$ Southwick, I, fol. 28v. Another version, III, fol. $24 \mathrm{v}^{\circ}$.

Pd. The cartularies of Southwick Priory, ed. Katharine A. HANNA, Winchester, Hampshire Record Office for Hampshire County Council, 1988-1989, p. 87-88

(English translation only).

22 Tiron

Geoffrey count of the Perche and his wife grant and confirm to the abbey of Tiron a payment of $£ 10$ on the Saturday after All Saints' day from the market at Nogent, 1192-1202.

Pd. Tiron, $\mathrm{n}^{\circ}$ CCCLXXVII, p. 160.

\section{Tiron}

Countess Matilda and Stephen of the Perche confirm the grant to the abbey of Tiron probably made by Count Geoffrey, which provided $£ 10$ a year from the prepositura of Mortagne, 100 s. on the feast of St Remy to light the church at Tiron and another $100 \mathrm{~s}$. on the last Sunday... for the anniversarium of Geoffrey the Percheron count, April-June 1202.

Pd. Tiron, $\mathrm{n}^{\circ}$ CCLXXVII, p. 164. 
24 Tiron

Stephen of the Perche and M the countess of the Perche's confirmation of Geoffrey of Beaumont's grant of $\mathfrak{E} 4$ to the abbey of Tiron is recorded in an abbey rental, April-June 1202 or 1190-1192.

Pd. Tiron, $n^{\circ}$ CCLXXVII, p. 160.

\section{Val-Dieu}

Geoffrey count of the Perche and Matilda his wife buy from Helois of Marches, by the hand of Prior William, the land which lay next to the grange of Boolai (? Boulay, Orne, cant. Mortagne, comm. Feings) on behalf of the charterhouse at Val Dieu. Helois, her mother Erembourg de Fracta and the lord of the fee, Arnold de Molendino received nearly $£ 25$ dunois for the sale, 1196-1202.

B = Alençon, Bibl. mun., ms 112, Recueil sur la Chartreuse du Val-Dieu, fol. 9.

\section{Val-Dieu}

Geoffrey [count of the Perche], son of the founder Rotrou, and his wife Matilda grant to the charterhouse of Val Dieu three measures of wine to be taken each year from the prepositura at Nogent-le-Rotrou, 1192-1202.

$\mathrm{C}=$ Alençon, Bibl. mun., ms 108, $\mathrm{n}^{\circ}$ 256, fol. 61 .

C2 = Paris, BnF, coll. Duchesne 54, p. 450.

\section{William Marshal}

A lost charter of Matilda countess of Perche, in which she undertakes her late husband's debt of 300 marks of silver to William Marshal, is recorded in letters patent of King John, before 22 April 1202.

Pd. Rotuli litterarum patentium in turri Londinensi asservati, 1201-1216, ed. Thomas. Duffus HARDY, London, 1834, 9b. 